\title{
Comparison of Physicochemical, Antioxidant Properties and Sensory Acceptance of Puree from Tamarillo and Tomato
}

\author{
Nur Zawin Nazihah Mohd Nor ${ }^{1}$, Faridah Kormin ${ }^{1,2}$, Siti Fatimah Zaharah Mohamad Fuzi ${ }^{1,2}$, Muhammad \\ Abdul Latiff Bin Abu Bakar ${ }^{1,2}$ \\ Department of Technology and Natural Resources, Faculty of Applied Sciences and Technology (FAST), Universiti Tun Hussein \\ Onn Malaysia (UTHM), Kampus Pagoh, KM1, Jalan Panchor 84000 Muar, Johor, Malaysia \\ ${ }_{2}$ Centre of Research for Sustainable Uses of Natural Resources (CoR-SUNR), Faculty of Applied Sciences and Technology, \\ Universiti Tun Hussein Onn Malaysia, Kampus Pagoh, 84000 Muar, Johor, Malaysia
}

Received 11 March 2018; accepted 2 November 2018; available online 12 November 2018

DOI: https://10.30880/jst.2018.10.03.005

\begin{abstract}
Puree is well known as the best food ingredient to enhance flavour in cooking. Tamarillo (Cyphomandra betacea) is an underutilized fruit in Malaysia due to their bland and strong sour taste. Tomato (Lycopersicon esculentum) is a well-known fruit that grows throughout the tropical and commonly consumed vegetable fruit. The purpose of this study are to determine and do a comparison on the physicochemical properties ( $\mathrm{pH}$, total soluble solid (TSS), moisture content, ash, protein, fat and carbohydrates) in tamarillo and tomato puree. In addition, this study was conducted to evaluate the antioxidant properties of tamarillo and tomato puree by using TPC and FRAP assay and lastly to evaluate the consumers acceptance on the new product (tamarillo puree) using sensory evaluation by 9 point hedonic test. Based on the results, tamarillo puree has lower $\mathrm{pH}$ value $(4.12 \pm 0.11)$, moisture content $(89.24 \pm 0.004 \%)$, and fat content $(0.2 \% \mathrm{wt} / \mathrm{wt})$ as compared to tomato puree $(\mathrm{pH}: 4.48 \pm 0.08$, moisture: $95.76 \pm 0.006 \%$, fat: $0.3 \% \mathrm{wt} / \mathrm{wt})$. Meanwhile, TSS value $\left(9.30 \pm 0.20^{\circ} \mathrm{Brix}\right)$, carbohydrate $(7.584 \% \mathrm{wt} / \mathrm{wt})$, $\mathrm{protein}$ $(1.0 \% \mathrm{wt} / \mathrm{wt})$ and ash content $(1.976 \%)$ of tamarillo puree was higher as compared to tomato puree (TSS: $3.30 \pm 0.10^{\circ}$ Brix, carbohydrate: $3.064 \% \mathrm{wt} / \mathrm{wt}$, protein: $0.09 \% \mathrm{wt} / \mathrm{wt}$, ash: $0.786 \%$ ). The TPC and FRAP value for tomato puree was $102.111 \pm 0.778 \mathrm{mg}$ of $\mathrm{GAE} / \mathrm{L}$ and $1.786 \pm 0.013 \mathrm{~g}$ of FSE/ml respectively, which were higher than tamarillo puree with value of $79.815 \pm 0.39 \mathrm{mg}$ of $\mathrm{GAE} / \mathrm{L}$ and $1.344 \pm 0.016 \mathrm{~g}$ of $\mathrm{FSE} / \mathrm{ml}$ respectively. Likewise for TFC value, tomato puree was higher $(9.389 \pm 0.394 \mathrm{RE} / \mathrm{L})$ as compared to tamarillo puree $(18.111 \pm 2.577 \mathrm{RE} / \mathrm{L})$. Results showed the comparison of physicochemical properties, antioxidant properties as well as consumer acceptability.
\end{abstract}

Keywords: Tamarillo; physicochemical properties; antioxidant properties; TPC; TFC; FRAP; sensory.

\section{Introduction}

Fruit puree is a thick liquid made by cooking and straining the fruits. It was stated by Europian Commision Regulation (EC) that puree contained about 3\% more water than sauce. While Prohens and Nuez defined tomato puree as tomato concentrate that contains no less than $7 \%$ but less than $24 \%$ of natural total soluble solids [1]. Fruit puree was an important ingredient that being used in many food products such as jams, marmalades, spread, filling and topping (UN Comtrade Database, 2009). The physiochemical properties of fruit puree were the important quality indicators that influences food acceptance [2] [3]. Malaysians loved to use puree especially tomato puree as an ingredient to enhance the taste of local cuisine. If the community in Malaysia concerned and aware on the importance of antioxidant and nutritional value of food, the development and evaluation of tamarillo puree is crucial to compare the properties against the well-known tomato purees.

Tamarillo also known as Cyphomandra betacea scientifically, is a subtropical fruit native to the Ecuadorian-Peruvian Andes. The types of tamarillo are distinguished by their colour which is red, yellow and purple [4] The fruit has 4-10 $\mathrm{cm}$ long and 3-5 $\mathrm{cm}$ in diameter [5]. Their red colour pigment of ripe tamarillo is due to the anthocyanins and the yellow-orange colour due to carotenoids. The ripe tamarillo is normally eaten raw by the local community in Kundasang. Tamarillo is remain underutilized in Malaysia, but in Colombia, it is a promising product for export due to its colour; the red variety has been most accepted internationally [5] [6].

Tomato (Lycopersicon esculentum) commonly referred as a vegetable that grown throughout the tropical and temperate regions of the world [7]. It is one of the most commonly cultivated and consumed vegetable fruit [8]. This 
fruits are typically grows about 1 to 3 meters in height, have a weak stem and perennial in its native habitat. It is commonly used as raw materials in food production such as purees and ketchup.

Codex Standard (1981) defined that tomato puree is considered as tomato concentrate that contains no less than $7 \%$ but less than $24 \%$ of natural total soluble solids, meanwhile tomato paste is defined as tomato concentrate that contains at least $24 \%$ of natural total soluble solids. There is stated in Food Regulations 1985 that tomato puree shall be the heat processed product made from whole, sound, ripe tomatoes, with the skin and seeds removed, concentrated to yield product with a specific gravity of not less than $1.050\left(20^{\circ} \mathrm{C} / 20^{\circ} \mathrm{C}\right)$. It shall be packed in hermetically sealed packages and processed by heat to prevent spoilage. It shall contain not less than $8 \%$ of soluble salt-free solids. It is also stated that tomato puree may contain permitted preservative.

The purpose of this study are to determine and do a comparison on the physicochemical properties $(\mathrm{pH}$, total soluble solid (TSS), moisture content, ash, protein, fat and carbohydrates) in tamarillo and tomato puree. In addition, this study was conducted to evaluate the antioxidant properties of tamarillo and tomato puree by using TPC and FRAP assay and lastly to evaluate the consumers acceptance on the new product (tamarillo puree) using sensory evaluation by 9 point hedonic test. Hence, this study is to evaluate whether tamarillo can be an alternative for tomato puree as they possess similar physicochemical, antioxidant properties as well as the acceptance by consumers.

\section{Materials and Methods}

Materials. Tamarillo was purchased from fresh market at Cameron Highlands and tomato was purchased at Pasar Mini Kim Seng at Pagoh, Muar, Johor.

Puree preparation. The fruits were washed and blanched for 2 minutes at $85^{\circ} \mathrm{C}$ and cooled using cold water. After that, it was peeled and the peeled-flesh was blended. The prepared puree was pasteurized at $60-75^{\circ} \mathrm{C}$ for 30 minutes. The end yield was the pasteurized puree.

Physicochemical analysis pH. The $\mathrm{pH}$ of both purees were measured using standard method with minor modification described by Horita et al., (2016) [9]. $10 \mathrm{~g}$ of sample was mixed well by stirring with $50 \mathrm{ml}$ of distilled water using glass rod and the $\mathrm{pH}$ of the suspension was determined in the $\mathrm{pH}$ meter.

Total Soluble Solid (TSS). TSS content of purees was determined by using Digital refractometer. All the experiments were conducted at room temperature [10].

Moisture content. The moisture content was determined using AOAC method 934.01. The samples were dried at $120^{\circ} \mathrm{C}$ and drying was continued till a constant reading was obtained. The moisture content was expressed as percentage [11].

Carbohydrates. Total carbohydrates content of the purees was obtained by using the method described by Mohammed Abdus Satter et al., (2016) [12], and was calculated as shown in Equation 1 [13]. The total carbohydrate was expressed in percentage.

$$
\begin{gathered}
\text { Total carbohydrates }=100-(\text { protein }+ \text { fat }+ \text { ash } \\
+ \text { moisture content })
\end{gathered}
$$

Protein. The protein content was estimated using Kjedhal method according to AOAC method 934.01, which analyzed the amount of nitrogen available in the sample [14]. $100 \mathrm{~g}$ of sample was transferred into digestion and $3 \mathrm{~g}$ of catalyst mixer and $10 \mathrm{ml}$ of concentrated sulfuric acid were added. It consisted of sodium or potassium sulfate and copper sulfate with ratio 5:1 respectively. The sample was digested until the solution became colourless. The digested sample was placed in the distillation unit for ammonia recovery. The sample was distilled and ammonia was collected in the receiver solution. The solution was titrated against the $0.1 \mathrm{~N}$ hydrochloric the colour changes (end point). The nitrogen value multiply by factor 6.25 gives the crude protein content of the sample in percentage.

Fat. The fat content of the sample was estimated by method according to AOAC method 945.18A. The lipid in the sample was extracted with petroleum ether $\left(110^{\circ} \mathrm{C}\right)$ in soxhlet apparatus for three hours. Then the solvent was dried overnight and the remaining residue was weighed. The fat content was expressed as percentage [11] [13].

Ash. Total ash was determined using muffle furnace as described by AOAC method 978.04 [11] [13]. The crucible was heated on the hot plate till it gave no fumes and then ignited in a muffle furnace at $550^{\circ} \mathrm{C}$ till greyish white residue were obtained. The ash content was expressed in percentage. 


\section{Antioxidant properties}

Total phenolic content (TPC). The total phenolic content of puree was determined by using Folin-Ciocalteu method with minor modification by Nallakurumban et al., (2015) and few references by Miliauskas et al., (2004) [14] [15]. $100 \mu \mathrm{l}$ of sample was mixed with $2 \mathrm{ml}$ sodium carbonate and left for 2 minutes at room temperature. Then, mixed with the same FolinCiocalteu reagent and left for 30 minutes. The absorbance reading was taken at $725 \mathrm{~nm}$. The phenolic content is expressed as $\mathrm{mg}$ of GAE/L.

Total flavonoid content (TFC). The content of flavonoids was determined by a Pharmacopeia method (1989) with few modifications which used rutin as a reference compound [16] [17]. One $\mathrm{ml}$ aliquot of extract puree was diluted with $4 \mathrm{ml}$ deionized water in $10 \mathrm{ml}$ volumetric flask. At zero time, $0.3 \mathrm{ml}$ of $10 \% \mathrm{AlCl}_{3}$ was added. After 6 minutes, $2 \mathrm{ml}$ of $1 \mathrm{M} \mathrm{NaOH}$ was added to the mixture. Then, immediately $2.4 \mathrm{ml}$ of deionized water was added to the reaction flask and mixed thoroughly and the absorption at 510 $\mathrm{nm}$ was read. The experiment was done in duplicate. The contents of flavonoid were calculated by comparing the absorbance value against the rutin standard.

Total antioxidant activity (FRAP). Total antioxidant activity was measure by ferric reducing antioxidant power (FRAP) assay with slight modification by Josipovic et al., (2016) [18]. Reagents included $250 \mathrm{ml}$ deionized distilled water, $4 \mathrm{ml} \mathrm{C}_{2} \mathrm{H}_{4} \mathrm{O}_{2}$ glacial acetic acid and $0.78 \mathrm{~g}$ sodium acetate were mixed in a volumetric flask as buffer; $0.31 \mathrm{~g}$ in TPTZ $((2,4,6-$ tripyridyl-s-triazine) in $100 \mathrm{ml}$ of $\mathrm{HCl}$ which 0.34 $\mathrm{ml}$ of $1 \mathrm{M} \mathrm{HCl}$ diluted in $100 \mathrm{ml}$ deinoized distilled water; $0.54 \mathrm{~g} \mathrm{FeCl}_{3}$ hexahydrate in 100 $\mathrm{ml}$ deionized distilled water. Working FRAP reagent was prepared by mixing $25 \mathrm{ml}$ acetate buffet, $2.5 \mathrm{ml}$ TPTZ solution and $2.5 \mathrm{ml}$ $\mathrm{FeCl}_{3} \cdot 6 \mathrm{H}_{2} \mathrm{O}$ solution. $100 \mu \mathrm{l}$ of sample added with $300 \mu \mathrm{l} \mathrm{H}_{2} \mathrm{O}$ was put together with the FRAP reagent. Absorbance reading was taken after 4 minutes. The FRAP value is expressed as $\mathrm{g}$ of ferrous sulphate/ml [17].

Sensory Evaluation. The sensory acceptance was determined by method proposed by Hidalgo and Almajano (2017) [19]. 50 trained panelists were chosen for this sensory evaluation. All panelists were asked to evaluate upon its overall acceptance (flavour, appearance, colour, odour and texture). First, panellists were asked to evaluate the samples and choose the acceptability on a structured hedonic scale $(9=$ most like, $5=$ neither like nor dislike and $1=$ most dislike) [20] as shown in Table 1.

Table 1. 9-Point Hedonic Scale

\begin{tabular}{|c|c|}
\hline 9 & Like Extremely \\
8 & Like Very Much \\
7 & Like Moderately \\
6 & Like Slightly \\
5 & Neither Like nor Dislike \\
4 & Dislike Slightly \\
3 & Dislike Moderately \\
2 & Dislike Very Much \\
1 & Dislike Extremely \\
\hline
\end{tabular}

\section{Results and Discussion.}

The results for physicochemical properties and antioxidant properties for both tamarillo and tomato purees were tabulated in Table 2 and Table 3 respectively. The tomato puree was made to compare between the overall sensory acceptance, antioxidant properties and physicochemical properties of tamarillo puree. The comparison was tabulated as indicated in Table 2.

Table 2. Physicochemical properties of tamarillo and tomato puree

\begin{tabular}{|c|c|c|}
\hline $\begin{array}{c}\text { Physicochemical } \\
\text { properties }\end{array}$ & $\begin{array}{c}\text { Tamarillo } \\
\text { puree }\end{array}$ & $\begin{array}{c}\text { Tomato } \\
\text { puree }\end{array}$ \\
\hline $\mathrm{pH}$ & $4.12 \pm 0.11$ & $4.48 \pm 0.08$ \\
TSS ( $\left.{ }^{\circ} \mathrm{Brix}\right)$ & $9.30 \pm 0.20$ & $3.30 \pm 0.10$ \\
Moisture (\%) & $89.24 \pm$ & $95.76 \pm$ \\
Carbohydrate (\% & 0.004 & 0.006 \\
wt/wt) & 7.584 & 3.064 \\
Protein (\% & 1.0 & 0.09 \\
wt/wt) & 0.2 & 0.3 \\
Fat (\% wt/wt) & 1.976 & 0.786 \\
Ash (\% wt/wt) & \\
\hline
\end{tabular}

Table 3. Antioxidant analysis of tamarillo and tomato puree

\begin{tabular}{|c|c|c|}
\hline $\begin{array}{c}\text { Antioxidant } \\
\text { analysis }\end{array}$ & $\begin{array}{c}\text { Tamarillo } \\
\text { puree }\end{array}$ & Tomato puree \\
\hline $\begin{array}{c}\text { TPC }(\mathrm{mg} \text { of } \\
\text { GAE/L) }\end{array}$ & $79.815 \pm 0.390$ & $102.111 \pm 0.778$ \\
$\begin{array}{c}\text { TFC }(\mathrm{mg} \text { of } \\
\text { RE/L) }\end{array}$ & $18.111 \pm 2.577$ & $9.389 \pm 0.394$ \\
$\begin{array}{c}\text { FRAP }(\mathrm{mg} \\
\text { FSE/L) }\end{array}$ & $1.344 \pm 0.016$ & $1.768 \pm 0.0134$ \\
\hline
\end{tabular}

Physicochemical analysis is a method to investigate the physicochemical properties and it can also be used for the determination of 
interaction between component of food which was related to the system's physical properties, composition, antioxidant properties and sensory acceptance [21].

The $\mathrm{pH}$, moisture content and fat of tamarillo were lower than tomato puree. Puree was classified as acid food $(\mathrm{pH}<4.6)$ [22]. Previous studies stated that the $\mathrm{pH}$ range of tamarillo and tomato puree were 3.09-4.75 and 4.26-4.82 respectively [23] [24] [25]. The result obtained from this study was within the range where tamarillo was 4.12 and tomato was 4.48. Moisture is important in influencing food quality, preservation and shelf-life factors [26]. Previous studies reported that the moisture content of tamarillo and tomato were $85.82 \%$ and $98.07 \%$ respectively [27] [28] [3] [29]. Both results showed similar values as previous researchers. Tomato puree has higher value of fat than tamarillo puree, 0.3 and $0.2 \%$ respectively. Previous studies claimed that the total fat content for tomato was $4.04 \mathrm{~g} / 100 \mathrm{~g}$, while for tamarillo varied from $0.2-0-5 \%$, which mean, the values found in this study fit this range [28] [30].

Likewise, TSS, carbohydrate, protein and ash value for tamarillo were higher than tomato puree. TSS in fruit generally was used to determine the concentration of sugar. The TSS of tamarillo puree was $9.30{ }^{\circ}$ Brix, higher than tomato puree which was $3.30^{\circ}$ Brix. Since the value of TSS was referred to the total amount of soluble constituents of puree, mainly sugars with smaller amounts of organic acids, vitamins, proteins, free amino acids, essential oil and glucosides [31], it was claimed that tamarillo puree had higher total amount of soluble constituents. Carbohydrates in tamarillo puree were higher than tomato puree with 7.584 and $3.064 \%$ respectively. US Department of Agriculture, Agricultural Research Service stated that tomato was $4.2 \%$ wet weight basis for carbohydrate value [32] while tamarillo's 3.7$4.6 \%$ [33]. Hence the values claimed by previous studies showed similar value for both purees.

US Department of Agriculture, Agricultural Research Service (2009) stated that the range for protein content varied from 0.2 to $2.0 \%$ wet weight basis while Lister et al., (2005) stated for tamarillo in the range of 1.8-2.0 [33]. The value obtained varied from previous studies which showed tamarillo and tomato purees protein content of only 1.0 and $0.09 \%$ but tamarillo's value fit the range reported by US Department of Agriculture, Agricultural Research Service. Total ash content determination in foods provides a measure of total amount of minerals since minerals are not destroyed by heating. The mineral content varies and depends on many factors, such as the variety of plant species, the terrain, the fertilization, and the climate. Moreover, it helps to estimate food quality, microbial stability and nutrition value. Lister et al., (2005) stated the range for ash for tamarillo was 0.78-1.5 [33], while Bakkali et al., (2009) claimed the ranged for fruit and vegetables to be between $0.2-1.0 \%$ [34]. The value of ash in this study fit the range by both group of researchers with tamarillo and tomato values of 1.976 and $0.786 \%$ of ash respectively.

The antioxidant of the purees was studied to compare both properties. As indicated in Table 3, the antioxidant analysis revealed that, TPC of tamarillo puree was $79.815 \pm 0.390 \mathrm{mg}$ of $\mathrm{GAE} / \mathrm{L}$ which indicated lower value than tomato puree with $102.111 \pm 0.778 \mathrm{mg}$ of GAE/L. It contradicted to the study done previously as it claimed that tomato should have lower TPC than tamarillo [7]. The condition of harvesting, storing and treatment method were able to affect the antioxidant properties of the processed fruit [22]. TFC of tamarillo puree was higher than tomato puree, which showed values of 18.1111 and $9.3889 \mathrm{~g}$ of RE/ml respectively. The higher TFC value indicated higher amount of antioxidant activity in tamarillo puree. Antioxidant activity by FRAP test of tamarillo puree was lower $(1.344 \pm 0.016 \mathrm{~g} \quad \mathrm{FSE} / \mathrm{ml})$ than tomato puree $(1.768 \pm 0.0134 \mathrm{~g} \mathrm{FSE} / \mathrm{ml})$. The higher of FRAP values might correlate with the tendency of polyphenols to become pro-oxidants activity. Thus, it can be concluded the highest value of FRAP means the lower the reducing power which serves as indicator of potential antioxidant activity [25] [35].

An ANOVA analysis by Microsoft Excel 10.0 for sensory evaluation on six attributes of the purees was applied. The value of "Prob $>F$ for sensory attributes sweetness, sourness, overall flavour, texture, appearance and overall acceptance are 0.0150, 0.0351, 0.0001, 0.0004, 0.0003 and 0.0004 respectively which were less than 0.05 . The judges can differentiate the puree since the results showed significance value $(\mathrm{p}<0.05)$ to all sensory attributes.

\section{Conclusions}

By comparing both purees, it can be concluded that tamarillo can be an alternative for tomato purees as they possess similar physicochemical, 
antioxidant properties as well as the acceptance by consumers. From the results obtained in this study, it was shown that tamarillo puree has lower $\mathrm{pH}$ value, moisture content and fat content as compared to tomato puree. Meanwhile, TSS value, carbohydrate, protein and ash content of tamarillo puree were higher as compared to tomato puree. The TPC and FRAP values for tomato puree were higher than tamarillo puree, however, TFC of tamarillo puree possess higher value. For sensory evaluation, the panelists were able to differentiate the puree since the results showed significance value $(\mathrm{p}<0.05)$ to all sensory attributes.

\section{Acknowledgement}

This study was financially supported by Research Management Centre (RMC) through the RACE grant (vote no. 1518) and RAGS grant vote no. R050 provided by the Universiti Tun Hussein Onn Malaysia (UTHM) in assistance with the government of Malaysia.

\section{References}

[1] J. Prohens and F. Nuez (2001) The tamarillo (Cyphomandra betacea), Small Fruits Review, 1, pp. 43-69.

[2] J. F. Meullenet (2009) Consumers and texture, Texture in Food. Cambridge: CRC Press, pp. 34.

[3] I. N. Gowda, K. H. Raman, N. Anand, A. T. Sadashiva and S. K. Tikoo (1994) Studies on the physicochemical characteristics and processing quality of Two II HR Tomato varieties in relation to commercial cultivars., Journal Food Science and Technology, vol. 31, no. 2, pp. 126-129.

[4] S. P. Gannasin, N. M. Adzahan, M. Hamzah, S. Mustafa and K. Muhammad (2015) Physicochemical properties of tamarillo (Solanum betaceum) hydrocolloid fractions, Food chemistry, vol. 182, no. 2, pp. 292-301.

[5] C. Vasco, J. Avila, U. Svanbeg and A. Kamal-eldin (2009) Physical and chemical properties of golden-yellow and purple-red varieties of tamarillo fruit (Solanum betacum), International Journal of Food Sciences anad Nutrition, vol. 60, no. S7, pp. 278-288.
[6] S. H. Ali Hassan and M. F. Abu Bakar (2013) Antioxidative and anticholinesterase activity of Cyphomandra betacea fruit, The Scientific World Journal, vol. 2013, pp. 1-7.

[7] S. U. Okorie, E. C. Nwanekezi and C. C. Okoro (2004) The quality properties of tomatoes as influenced by processing with a chemical preservative and storage, Nigerian Food Journal, vol. 22, pp. 195197.

[8] M. Temesgen, T. S. Workneh and G. Bultossa (2011) Effect of tomato cultivars, honey finisher and processing methods on quality of tomato ketchup, African Journal of Biotechnology, vol. 22, pp. 1881-185.

[9] C. N. Horita, A. M. Far'ias-Campomanes, T. S. Barbosa, E. A. Esmerino, A. G. da Cruz, H. Bolini, M. Meireles and M. Pollonio (2016) The antimicrobial, antioxidant and sensory properties of garlic and its derivatives in Brazillian low-sodium frankfurters along shelf-life, Food Research International, vol. 84, pp. 1-8

[10] R. A. Zuhair, A. Aminah, A. M. Sahila and D. Eqbal (2013) Antioxidant activity and physicochemical properties changes of papaya (Carica papaya L. cv. Hong Kong) during different ripening stage, International Food Research Journal, vol. 20, no. 4, pp. 1653-1659.

[11] AOAC (2000) Official method of analysis, in Association of official analytical chemists 15th Edition, Washington D.C, pp. 430, 918, 990.

[12] M. Mohammed Abdus Satter, M. Khan, S. A. Jabin, N. Abedin, M. F. Islam and B. Shaha (2016) Nutritional quality and safety aspects of wild vegetables consumed in Bangladesh, Asian Pacific Journal of Tropical Biomedicine, vol. 6, no. 2, pp. 125-131.

[13] S. S. Nielsen (2010) Food Analysis, Springer.

[14] P. Nallakurumban, N. Suja, A. Vijayakumar, P. S. Geetha and L. Karpagapandi (2015) Estimation of phytochemicals and antioxidant properties of tamarillo (Solanum betaceum) and a value added product tamarillo sauce, International Journal of Scientific Progress and Research, vol. 9, no. 2, pp. 61-65. 
[15] G. Miliauskas, P. Venskutonis and T. Van Beek (2004) Screening of radical scavenging activity of some medicinal and aromatic plant extracts, Food Chemistry, 85, pp. 231-237.

[16] A. N. Sheehata, A. E. Mahmoud and H. M. Abdou (2014) Quantification of total phenoloc and total flavonoid contents in extracts of some Egyptian green leaves and estimation of antioxidant activity, Research Journal of Pharmaceutical, Biological and Chemical Sciences, vol. 5, no. 6, pp. 266273.

[17] M. Abu Bakar, F. Abdul Karim, M. Suleiman, A. Isha and A. Rahmat (2015) Phytochemical constituents, antioxidant and antiproliferative properties of a Liverwort, Lepidozia borneensis Stephani from Mount Kinabalu, Sabah, Malaysia, vol . 2015, pp. 1-9.

[18] A. Josipovic, R. Sudar, A. Sudaric, V. Jurkovic, M. M. Kocar and A. M. Kulundzic (2016) Total phenolic and and total flavonoid content variability of soybean genotypes in Eastern Croatia, Croat, Journal Food Science Technology, vol. 8, no. 2, pp. 60-65.

[19] G. Hidalgo and M. P. Almajano (2002) Red fruits: Extraction of antioidants, penolic content and radical scavenging determination: A review, Antioxidant, vol. 6, no. 1, pp. 19.

[20] C. Lange, C. Martin, C. Chabanet, P. Combris and S. Issanchou (2002) Impact of the information provided to consumers on their willingness to pay for Champage: comparison with hedonic scores, Food Quality and Preference, 13, pp. 597-608.

[21] J. A. Breznak and R. N. Costilow (2007) Physicochemical factors in growth," in Methods for general and molecular microbiology, Third Edition, Washington, DC, ASM Press, pp. 309-327.

[22] E. Garcia and D. M. Barret (2005) Evaluation of processing tomatoes from two consecutive growing seasons: Quality attribute, peelability and yield, Journal of Food Processing and Preservation, vol. 30, no. 1, pp. 20-36.

[23] A. A. Ajayi and I. G. Olasehinde (2009) Studies on the $\mathrm{pH}$ anf protein content of tamarillo (C. betacea) fruit, The Scientific
Research and Essay, vol. 4, no. 3, pp. 185187.

[24] A. Davies, "Advances in modifiedatmosphere packaging," in New methods of food preservstion, Springer, 1995, pp. 304320.

[25] G. K. Rai, R. Kumar, A. K. Singh, P. K. Rai, M. Rai, A. K. Chaturvedi and A. B. Rai (2012) Changes in antioxidant and phytochemical properties of tomato (Lycopersion esculentum) under ambient temperature, Pak. Journal Bot., vol. 44, no. 2, pp. 667-67.

[26] J. Hanson (2017) Refracrometry. Retrieved on March 10, 2017, From http://www.ups.edu/faculty/hanson/labtech niques/Refractometry/intro.html".

[27] S. P. Gannasin, Y. Ramakrishnan, N. Mohd Adzahan and K. Muhammad (2012) Functional and preliminary characterisation of hydrocolloid from tamarillo (solanum betaceum Cav.) puree, Molecules, vol. 17, pp. 6869-6885.

[28] J. F. Morton (1982) The tree tomato; a fast growing, early-fruiting small tree for subtropical climates, Proc. Fla. State Hort. So., vol. 95, pp. 81-85.

[29] R. Loiudice, M. Impembo, M. Laratta, G. Villari, A. Lovoi and P. Siviero (1995) Composition of San Marzano tomato varieties, Food Chemistry, vol. 53, no. 1, pp. 81-89.

[30] E. Elbadrawy and A. Sello (2016) Evaluation of nutritionl value and antioxidant activity of tomato peel extracts, Arabian Journal of Chemistry, vol. 9, no. 2, pp. S1010-S1018.

[31] P. Forero, C. E. Orrego, D. G. Peterson and C. Osorio (2015) Chemical and sensory comparison of fresh and dried lulo (Solanum Quitoense Lam.) fruit aroma, Food Chemical, vol. 169, no. 1, pp. 85-91.

[32] J. N. Bemiller (2007) Carbohydrate Chemistry for Food Scientists, 2nd Edition, St. Paul, M.N: AACC International.

[33] C. E. Lister, S. C. Morrison, N. S. Kerkhofs and K. M. Wright (2005) The nutritional composition and health benefits of New Zealand tamarillos, Christchurch, New Zealand.

[34] K. Bakkali, N. R. Martos, B. Souhail and E. Ballesteros (2009) Characterization of trace 
metals in vegetables by graphite furnace atomic absorption spectrometry after closed vessel microwave digestion, Food Chemistry, vol. 116, no. 2, pp. 590-594.

[35] R. L. Prior, X. Wu and K. Schaich (2005) Standardized method for determination of antioxidant capacity and phenolic in food and dietary supplement," Journal Agricultural \& Food Chemistry, vol. 53, pp. 4290-4302. 